\title{
Pain relief in active patients with cancer: the early use of nerve blocks improves the quality of life
}

\author{
Sampson Lipton
}

Most patients with cancer have pain. ${ }^{12}$ In one series $77 \%$ of the pain was due to cancer, $19 \%$ resulted from treatment, and $4 \%$ was unconnected with the cancer. ${ }^{3}$ When morphine and other drugs are used to relieve pain about $80 \%$ of patients obtain relief, $10 \%$ have intolerable side effects, and $10 \%$ have no relief. For relief to occur the narcotic drug must cross the bloodbrain barrier to affect spinal opioid receptors. This does not happen in some patients when the drugs are given orally or parenterally as shown by their concentrations in cerebrospinal fluid (C Wells, personal communication).

\section{Relief of pain}

Twenty per cent of patients with pain from cancer do not obtain satisfactory relief with narcotics in combination with other drugs. In the Liverpool pain clinic, which works closely with the local Marie Curie Home, roughly a quarter of this $20 \%$ have cordotomies, ${ }^{4}$ a quarter are given coeliac plexus blocks, ${ }^{5}$ a quarter are given drug delivery systems, and the remaining quarter have miscellaneous blocks and other treatment. About $80 \%$ of them become free of pain - that is $16 \%$ of the $20 \%$ who find no relief with drugs alone.

Overall therefore $96 \%$ of patients in pain from cancer can obtain relief by a combination of drug treatment and nerve blocks. In my experience a localised destructive procedure is better than giving a narcotic to the whole body just to get some of it into the cerebrospinal fluid. Patients would find it more advantageous if less morphine and more blocks were used as the quality of pain relief when a block works well is much better than that obtained when narcotics work well.

\section{Methods}

The failure of narcotics to reach central opioid receptors can be overcome by subarachnoid catheter injection, but there are still a few patients who find no relief even then. The vascularity of the epidural space tends to increase with repeated injections, thus producing higher blood concentrations than expected. In the Liverpool clinic intrathecal catheters with a totally implanted system are used (figure). In patients who have not taken morphine before there are three main complications - namely, itching, which settles in a few days; respiratory depression, which is rare and can be treated with naloxone without much affecting the analgesia; and sepsis. In patients who have previously received morphine orally or parenterally

Br Med J 1989;298:37-8

Liverpool L9

Sampson Lipton, FFARCS, medical director

Common repeatable destructive procedures in managing cancer pain with efficacy and main complications

\begin{tabular}{lll}
\hline \multicolumn{1}{c}{ Procedure } & \multicolumn{1}{c}{ Efficacy } & \multicolumn{1}{c}{ Main complications } \\
\hline $\begin{array}{l}\text { Percutaneous cordotomy } \\
\begin{array}{l}\text { Intrathecal phenol injection: } \\
\text { Lumbar } \\
\text { Dorsal }\end{array}\end{array}$ & Six months to one year (often longer) & $\begin{array}{l}\text { Temporary ipsilateral weakness, } \\
\text { Horner's syndrome }\end{array}$ \\
$\begin{array}{l}\text { Phenol drop injection: } \\
\text { Caudal }\end{array}$ & $\begin{array}{l}\text { Two months maximum } \\
\text { Three months maximum }\end{array}$ & $\begin{array}{l}\text { Analgesia, weakness controlled by dose } \\
\text { Analgesia }\end{array}$ \\
$\begin{array}{lll}\text { Coeliac plexus block } \\
\text { Lumbar sympathetic block }\end{array}$ & Two months maximum & $\begin{array}{l}\text { Bladder dysfunction minimised by } \\
\text { phenol drop technique, strength and } \\
\text { dose titrated over three injections }\end{array}$ \\
& Three weeks to three months & $\begin{array}{l}\text { Hypotension } \\
\text { Genitofemoral neuralgia }\end{array}$ \\
\hline
\end{tabular}

and have adapted to the drug there is no itching and no respiratory depression; sepsis is the only problem.

The destructive methods available are much wider than is commonly thought, including nerve blocks, which can be peripheral, central, or autonomic with chemical, ${ }^{6}$ cryoprobe, ${ }^{7}$ or radiofrequency destruction; percutaneous $^{4}$ or open cordotomy; thalamotomy; injection of alcohol into the pituitary gland ${ }^{8}$; mechanical fixation of painful mobile vertebrae or fractured long bones; and massive palliative neurosurgical operations on selected invading ethmoid, orbital, and aural tumours. Radiotherapy is not usually an invasive procedure but even when no further large dose can be given, treating a solitary nodule or fracture site will relieve pain. Cytotoxic drugs have similar useful applications.

Of course there is a rate of failure and recurrence with all methods, but these are improved with persistence. If nerve blocks and the other active methods are to make their full contribution an aggressive attitude to pain relief has to be adopted with meticulous attention to the details of each procedure. At the end of life all patients need tender loving care, personal and family support, and as much pain relief as possible by whatever method possible-drugs or active procedures. Giving drugs starts too early in many cases, probably because the skill necessary for successful blocks is not widely available. A close relation between a hospice and hospital pain clinic with its battery of pain relieving techniques is ideal but is only available in a few places in this country.

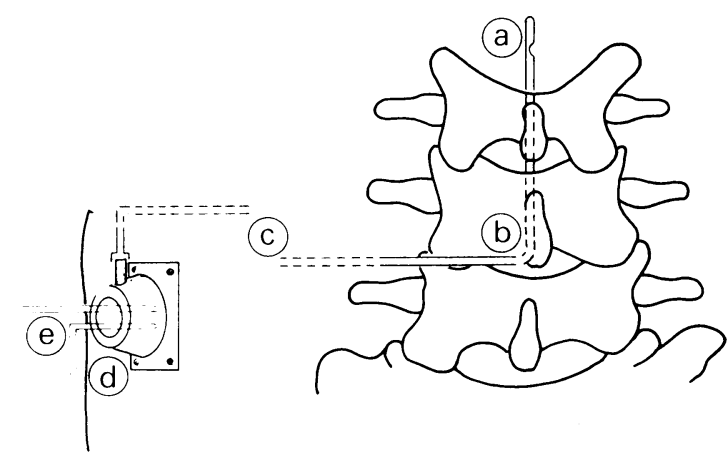

Diagram of intrathecal catheter with totally implanted system. (a) Epidural catheter tip; (b) catheter inserted into epidural space through a Tuohy or similar epidural needle; (c) connecting tubing; (d) subcutaneous Pharmacia type port; (e) straight or angled non-coring needles inserted through skin into port. They may be connected to drip, syringe driver, or electronic pump. This method also allows narcotic solutions to be replaced by local anaesthetics to "rest" spinal receptors if tolerance, hyperalgesia, or tachyphylaxis develops. Normal sensitivity usually returns in one to two weeks

\section{Expectation of life}

A short expectation of life means under two years and, in most cases, much less than that. In the context of this article patients with active cancer have a life expectancy of about three months. As most ablative procedures give pain relief for at least six weeks they can be used and repeated if they do not last the full three months. Over six or more months repeated blocks may be necessary as cancer is progressive. My own preference would be to go straight to percutaneous cordotomy as it relieves pain superbly. The table gives details of the effectiveness and complications of this 
Controversies in Therapeutics and other techniques. It is not comprehensive so refer to original papers for full details.

The injection of alcohol into the pituitary is in a different class. It is used for widespread, severe cancer pain, for pain in the head and neck, and when drug treatment and other techniques are inadequate. Forty per cent of patients obtain complete relief of pain for up to three months, $30 \%$ partial relief, and $30 \%$ no relief.

\section{Summary}

Analgesic drugs are the first line of pain relief in cancer, but they should not be the only treatment offered. If nerve blocks and other destructive procedures are to be used they should be used early with conviction and persistence. They might not be being used because there are not enough doctors who can use them properly.

1 Bonica JJ, ed. Cancer pain. New York: Raven, 1980:335-62.

2 Twycross RG, ed. Clinics in oncology. London: Saunders, 1984:5-15.

3 Foley KM. Pain syndromes in patients with cancer. In: Bonica JJ, Ventafridda $\mathrm{V}$, eds. Advances in pain research and therapy. Vol 2. New York: Raven, 1979:59-77.

4 Lipton S. Percutaneous cordotomy. In: Wall PD, Melzack R, eds. Textbook of pain. 1st ed. Edinburgh: Churchill Livingstone, 1984:632-8.

5 Thompson GE. Celiac plexus, intercostal, and minor peripheral blockade. In Cousins MJ, Bridenbaugh PO, eds. Neural blockade. Ist ed. Philadelphia: Lippincott, 1980:394-7.

6 Maher R, Mehta M. Spinal (intrathecal) and extradural analgesia. In: Lipton S, ed. Persistent pain. Vol 1. London: Academic, 1977:61-9.

7 Lloyd JW, Barnard JDW, Glynn CJ. Cryoanalgesia; a new approach to pain relief. Lancet 1976;ii:932-4.

8 Miles J. Pituitary destruction. In: Wall PD, Melzack R, eds. Textbook of pain. Ist ed. Edinburgh: Churchill Livingstone, 1984:656-65.

\section{Mary Baines}

continued from page 36 morphine because neurolytic and neurosurgical blocks are rarely available for they must be carried out by experienced specialists in a hospital or clinic. By contrast, the basic principles of managing pain with analgesics are remarkably easy to learn. After attending a week's workshop Takeda returned to Japan to test WHO's guidelines on the relief of cancer pain. ${ }^{+}$He found that over $80 \%$ of his patients became free of pain with drug treatment alone. ${ }^{8}$

There remains a small but important group, perhaps $5-10 \%$ of patients with cancer, who benefit from invasive procedures if they are available. These include

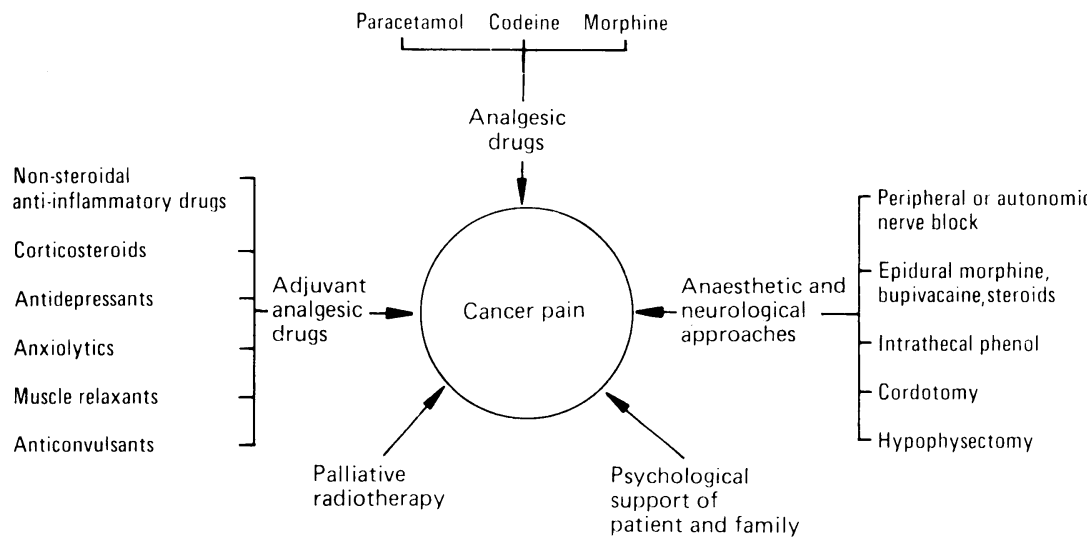

Treatment of cancer pain some with specific, localised pains, such as pancreatic or chest wall pain, which can be treated with appropriate nerve blocks. In addition, there is a small but as yet undefined group with intractable pain who will benefit from epidural or intrathecal drugs, or perhaps from a neurosurgical approach.

\section{Conclusion}

Over the past 20 years there has been a great upsurge of interest in the relief of cancer pain and reports indicate that the situation is improving. ${ }^{9}$ This change has been due to the much wider and more informed use of strong opioid drugs, but there still remains a small but important place for neural blockade.

Bonica JJ. Importance of the problem. In: Swerdlow M, Ventafridda V, eds. Cancer pain. Lancaster: MTP, 1987:3-7.

2 Foley KM. The management of pain of malignant origin. In: Tyler HR, Dawson DM, eds. Current neurology. Vol 2. Boston: Houghton Mifflin, 1979:279-302.

3 Bonica JJ. Treatment of cancer pain: current status and future needs. In: Field $\mathrm{HL}$, et al, eds. Advances in pain research and therapy. Vol 9. New York: Raven, 1985:589-616.

4 World Health Organisation. Cancer pain relief. Geneva: WHO, 1986.

5 Craig KD. Psychology of pain. Postgrad Med f 1984:60:835-40.

6 Twycross RG, Lack SA. Symptom control in far advanced cancer: pain relief. London: Pitman 1983:20-1.

Price P, Hoskin PJ, Easton D, Austin S, Palmer SG, Yarnold JR. Prospective randomised trial of single and multifraction radiotherapy schedules in the randomised trial of single and multifraction radiotherapy schedules in
treatment of painful bony metastases. Radiother Oncol 1986;6:247-55.

Takeda F. Results of field testing in Japan of the WHO draft interim guideline on relief of cancer pain. The Pain Clinic 1986;1:83-9.

9 Parkes CM, Parkes J. "Hospice" versus "hospital" care-re-evaluation after 10 vears as seen by surviving spouses. Postgrad Med $\mathcal{F}$ 1984;60:120-4

\section{WORDS}

JANUS WORDS Some words have two meanings each of which is the reverse, or nearly so, of the other. They have the same sound and may have the same spelling. There are also words that have reversed their meanings with the passage of time. In my private vocabulary I call this mixed bag Janus words, after the god in Roman mythology who was represented with two faces looking in opposite directions. No proprietary rights are claimed for my private vocabulary; please go ahead.

Here are some common examples. We climb the FELLS and go up the DOWNS. The German $a b$, pronounced "up," now naturalised in "abseiling," means "down." The expression "RAZED to the ground" perversely evokes in my mind's eye a group of Welsh miners who have just returned from the depths. CHUFFED, which until recently meant disgruntled, now means delighted. EGREGIOUS (L egregius; from ex, out + grege, from the flock), originally meant distinguished, excellent, and now means notorious. CLEAVE can mean "split, separate" or "adhere, unite." In the terminology of films a TRAILER precedes the film it advertises; in all other contexts it follows. A DIATRIBE once meant a discourse; it now means an invective harangue. In this connection, see Bernardo Ramazzini's De Morbis Artificum Diatriba (1700), the first book on occupational diseases.

ASPIRATE means "suck" in medical terminology and "blow" in phonetics. Thus we aspirate secretions from the bronchi, fluids from joints and serous cavities, and air from pneumothoraces. Patients may develop aspiration pneumonia owing to changes in the structure or function of the deglutition pathway, and most seriously perhaps from inhaled vomit. In phonetics, by contrast, an aspirate is the sound of the letter $\mathrm{H}$, and, more usually now, the $\mathrm{H}$ sound added to a vowel or consonant. This occurs, for example, in the word "pin," during that brief moment between the unvoiced $\mathrm{p}$ - and the voiced -in, (40-70 msec according to Gimson'). "Aspirate" derives from L aspiro (from ad + spiro), to breathe upon, to exhale. So the medical meaning branched off and reversed its direction. L spiro, to breathe, gave us "spirit" when breath (anima) was connected in mediaeval thinking with "soul." We now have, of course, respiration, expiration, and inspiration - this last also much used as a descendent of its ancient meaning. Transpire and perspire, by extension, are the emission of vapour from plants and animals respectively. Conspire ( $\mathrm{L}$ con, with) is to breathe together-obviously in a close huddle. Many will know the old tag, Dum spiro, spero (while I breathe, I hope)- often untrue, as every doctor knows. The surname Spiro, and its variant Shapiro, is Jewish and denotes an origin in the ancient German town of Speyer. In the United States Spiro is also the curtailed Greek surname Spiros, in turn from Spiridon. Spiro would be a fine name for a specialist in lung diseases, especially in the United Kingdom, where advertising is currently forbidden to doctors. B J FREEDMAN

1 Gimson AC. An introduction to the pronunciation of English. 3rd ed. London: Arnold, 1980:153. 